\title{
PENGARUH SISTEM PENGENDALIAN INTERNAL PEMERINTAH (SPIP) DAN PERAN KOMITE SEKOLAH TERHADAP PENCEGAHAN FRAUD PENGELOLAAN DANA BANTUAN OPERASIONAL SEKOLAH (BOS) PADA SMP NEGERI DI BANDA ACEH
}

\author{
Lisa Rahmadhani ${ }^{1}$, Suparno ${ }^{* 2}$ \\ 1,2 Program Studi Akuntansi Fakultas Ekonomi Universitas Syiah Kuala \\ e-mail: lisa.rahmadhani@gmail.com ${ }^{1}$, suparno.feakt@ unsyiah.ac.id $^{* 2}$ \\ * Corresponding Author
}

\begin{abstract}
This study aims to determine the effect of the Government Internal Control System (SPIP) and the role of school committee on the fraud prevention of management of school operational funds (BOS). The population of this research were headmaster, vice principal, and BOS treasurer of 19 Junior High Schools in Banda Aceh with the total 57 respondents. The research was conducted by using census method. The data source in this study are primary data obtained from questionnaires to the respondents. The testing of the influences of independent variables toward dependent variable was done by using multiple linear regressions model. The results of this research show that both partially simultaneously, Government Internal Control System (SPIP) and the role of school comittee are significantly influential to the fraud prevention of management of school operational funds (BOS) of Junior High Schools in Banda Aceh.
\end{abstract}

Keywords: Fraud Prevention, SPIP, the role of school committee, BOS funds

\section{Pendahuluan}

Kecurangan (fraud) adalah tindakan yang mengandung unsur kesengajaan, menguntungkan diri sendiri atau orang lain, penipuan, penyembunyian atau penggelapan, dan penyalahgunaan kepercayaan yang bertujuan untuk memperoleh keuntungan secara tidak sah yang dapat berupa uang, barang/harta, jasa, dan tidak membayar jasa, yang dilakukan oleh satu individu atau lebih dari pihak yang bertanggung jawab atas tata kelola, pegawai, atau pihak ketiga (Badan Pemeriksa Keuangan Republik Indonesia, 2007). Association of Certified Fraud Examiners (ACFE, 2014) mendefinisikan fraud sebagai sebuah perbuatan melawan hukum yang dilakukan dengan sengaja untuk tujuan tertentu yang dilakukan oleh orang-orang dari dalam atau luar organisasi untuk mendapatkan keuntungan pribadi ataupun kelompok yang secara langsung atau tidak langsung merugikan pihak lain dengan maksud untuk mendapatkan keuntungan pribadi atau kelompoknya. Dapat disimpulkan bahwa oleh orangorang dari dalam dan atau luar organisasi untuk mendapatkan keuntungan pribadi atau kelompoknya.
ACFE (2010) mengkategorikan kecurangan ke dalam tiga kelompok yaitu: (1) Kecurangan Laporan Keuangan (Financial Statement Fraud), Penyalahgunaan aset (Asset Misappropriation), dan (3) Korupsi (Corruption). Berdasarkan hasil survei yang dilakukan oleh ACFE Indonesia pada tahun 2016, korupsi adalah jenis fraud yang paling banyak terjadi dan yang paling merugikan di Indonesia dibandingkan dengan kecurangan laporan keuangan dan penyalahgunaan aset (ACFE Indonesia Chapter, 2016). Hasil pengukuran untuk tingkat korupsi di Indonesia yang dilakukan oleh Transparancy International menunjukkan hasil pengukuran Corruption Perception Index (CPI) Indonesia tahun 2018 mencapai skor 38 dan menempati peringkat 89 dari 180 negara yang diukur. Skor CPI berada pada rentang 0 100, skor 0 berarti bahwa Negara dipersepsikan sangat banyak melakukan korupsi, sementara skor 100 berarti dipersepsikan sangat bersih dari korupsi (Transparency International, 2018).

Jumlah fenomena fraud di Indonesia terus mengalami peningkatan dari tahun ke tahun dan terjadi 
di berbagai sektor, termasuk salah satunya adalah sektor pendidikan. Sektor pendidikan harus menjadi tempat yang benar-benar bersih dari fraud, terutama korupsi. Namun, faktanya justru di bidang pendidikan paling banyak ditemukan tindakan korupsi baik di provinsi maupun kabupaten/kota. Nilai kerugian negara akibat korupsi sektor pendidikan mencapai jumlah 1,3 Triliun Rupiah. Data tersebut dirilis Indonesian Corruption Watch (ICW) yang telah melakukan pemantauan terhadap korupsi di sektor pendidikan dan tercatat sebanyak 425 kasus korupsi sektor pendidikan yang terjadi selama tahun 20062015. Nilai suap dalam kasus korupsi sektor pendidikan juga tergolong cukup tinggi, yaitu mencapai angka 55 Milyar Rupiah. ICW juga melakukan penelusuran terhadap objek yang rentan dikorupsi dan terdapat 17 objek yang rawan dikorupsi pada sektor pendidikan, termasuk salah satunya adalah Dana Bantuan Operasional Sekolah (BOS) (Anti Korupsi, 2016).

Dana BOS merupakan program pemerintah untuk membiayai kegiatan nonpersonalia sekolah untuk mewujudkan program wajib belajar (Silele et al., 2017). Seperti yang telah disebutkan dalam UU Negara RI pasal 31 ayat (2) bahwa "setiap warga negara wajib mengikuti pendidikan dasar dan pemerintah wajib membiayainya". Pemerintah telah mengatur penggunaan dan pertanggungjawaban dana BOS ini dalam Petunjuk Teknis sesuai Peraturan Menteri Pendidikan dan Kebudayaan Republik Indonesia dari mulai 2005 hingga tahun 2018, namun dalam prakteknya masih banyak terdapat kecurangan atau fraud dalam pengelolaan dana BOS yang dilakukan oleh pihak tertentu untuk mengambil keuntungan.

Beberapa penyimpangan dana BOS yang muncul seperti pungutan liar, penyuapan, dan tidak mematuhi Petunjuk Teknis Penggunaan Dana BOS. Tertangkapnya Kepala Dinas Pendidikan Langkat bersama 10 orang lainnya dalam operasi tangkap tangan oleh Polisi Daerah Sumatera Utara. Mereka diduga telah melakukan pungutan liar dana BOS terkait indikasi pemotongan dana untuk setiap siswa (Detiknews, 2017). Kemudian tidak sedikit pula kepala sekolah yang harus berurusan dengan hukum bahkan berujung penjara setelah terbukti menyelewengkan dana BOS, seperti pada kasus korupsi dana BOS yang terjadi di Nagan Raya, Majelis Hakim Pengadilan Tindak Pidana
Korupsi Banda Aceh menjatuhkan vonis satu tahun penjara terhadap mantan Kepala SMP Negeri 5 Suka Makmue, Kabupaten Nagan Raya terkait tindak pidana korupsi dana BOS yang dilakukannya pada tahun 2015 dengan kerugian negara mencapai Rp264 juta lebih (Aceh Tribunnews, 2017).

Maraknya terjadi fraud pada Dana BOS maka diperlukannya sebuah tindakan yang disebut pencegahan fraud, karena pencegahan terhadap terjadinya suatu perbuatan kecurangan akan lebih mudah daripada mengatasi bila kecurangan telah terjadi. Pencegahan fraud pada umumnya adalah tindakan-tindakan yang dilakukan untuk mencegah perbuatan fraud sebelum terjadi. Menurut Karyono (2013:47), pencegahan fraud merupakan segala upaya untuk menangkal pelaku potensial, mempersempit ruang gerak, dan mengidentifikasi kegiatan yang beresiko tinggi terjadinya kecurangan. Menurut Karyono (2013:61), cara yang paling mendasar untuk mencegah terjadinya fraud yaitu dengan mencegahnya melalui 3 faktor utama penyebab fraud itu sendiri yang dikenal dengan "Fraud Triangle Theory" yaitu Tekanan, Kesempatan, dan Pembenaran. Sehingga langkah-langkah yang harus dilakukan yaitu; (1) mengurangi tekanan situasional yang menyebabkan kecurangan, (2) mengurangi kesempatan melakukan kecurangan, (3) mengurangi pembenaran melakukan kecurangan dengan memperkuat integritas pegawai.

Salah satu faktor yang berpengaruh terhadap pencegahan fraud yaitu dengan adanya pengendalian internal. Menurut Tuannakotta (2017:162), pencegahan fraud dapat dilakukan dengan mengaktifkan pengendalian internal. Apabila pengendalian intern dalam suatu entitas telah efektif, maka dapat memberikan perlindungan bagi entitas terhadap kelemahan manusia serta untuk mengurangi kemungkinan kesalahan dan tindakan yang tidak sesuai dengan aturan.

Dana BOS merupakan program pemerintah untuk menyediakan dana nonpersonalia bagi satuan pendidikan dasar, sehingga dalam hal ini perlu adanya sistem pengendalian langsung dari pemerintah untuk mengatur pendistribusian dana yang disebut Sistem Pengendalian Internal Pemerintah atau SPIP. Menurut Peraturan Pemerintah No. 60 tahun 2008 pasal 1 ayat (1), "SPIP adalah proses yang integral pada kegiatan dan tindakan yang dilakukan secara terus menerus oleh 
pimpinan dan tercapainya tujuan organisasi melalui kegiatan yang efektif dan efisien, keandalan pelaporan keuangan, pengamanan aset negara, dan ketaatan terhadap peraturan perundang-undangan".

Penelitian ini merujuk pada penelitian Pura \& Sufiati (2014) yang menguji pengaruh internal control terhadap pencegahan fraud atas pengelolaan dana BOS. Hasil penelitian tersebut menunjukkan bahwa pengendalian internal berpengaruh positif dan signifikan terhadap pencegahan fraud atas pengelolaan dana BOS. Artinya bahwa dengan adanya pengendalian internal maka akan semakin baik pencegahan fraud sehingga akan mengurangi kecenderungan pengelola dana BOS melakukan fraud. Penelitian ini sejalan dengan penelitian yang dilakukan oleh Ariastini et al., (2017) yang menguji pengaruh SPIP terhadap pencegahan fraud pengelolaan dana BOS yang menunjukkan bahwa SPIP berpengaruh positif dan signifikan terhadap pencegahan fraud atas pengelolaan dana BOS. Beberapa penelitian terdahulu lainnya yang menguji pengaruh pengendalian internal terhadap pencegahan fraud juga telah dilakukan oleh Joseph et al., (2014), Yuniarti (2017), dan Muliawan et al., (2017) yang menemukan bahwa pengendalian intern berpengaruh signifikan terhadap pencegahan fraud. Hal tersebut menunjukkan jika suatu organisasi yang memiliki sistem pengendalian internal yang lemah, maka cenderung akan meningkatkan peluang terjadinya kecurangan di dalam organisasi tersebut. Artinya semakin baik sistem pengendalian internal, maka akan semakin rendah tingkat terjadinya fraud..

Faktor lain yang dapat mempengaruhi pencegahan fraud pengelolaan dana BOS yaitu peran komite sekolah. Selain mewujudkan peran serta dalam mendukung peningkatan mutu pendidikan, komite sekolah juga memiliki peran sebagai pengawas untuk kesepakatan guna mencapai sekolah yang mandiri dan berprestasi. Komite Sekolah adalah badan mandiri yang mewadahi peran serta masyarakat dalam rangka meningkatkan mutu, pemerataan, dan efisiensi pengelolaan pendidikan di satuan pendidikan, baik pada pendidikan pra sekolah, jalur pendidikan sekolah maupun jalur pendidikan di luar sekolah (Kepmendiknas nomor: 044/U/2002,7).

Penelitian sebelumnya yang dilakukan oleh Cahyanto (2014) menguji pengaruh peran komite sekolah terhadap pengelolaan Dana BOS. Hasil penelitiannya menunjukkan bahwa komite sekolah berpengaruh positif dan signifikan terhadap Pengelolaan Dana BOS. Hal tersebut membuktikan bahwa dengan adanya peran yang tepat dari komite sekolah maka akan memberikan kontrol terhadap pengelolaan Dana BOS sehingga dana BOS akan terhindar dari segala bentuk penyebab terjadinya fraud

\section{Kajian Pustaka, Kerangka Pemikiran Dan Hipotesis \\ Pencegahan Fraud}

Menurut BPK RI (2017), fraud didefinisikan sebagai "segala bentuk aktivitas yang menguntungkan diri sendiri atau orang lain dengan cara melakukan penipuan, penggelapan, dan menyalahgunakan wewenang dengan maksud untuk merugikan pihak lain. Berdasarkan pernyataan tersebut, disimpulkan bahwa kecurangan adalah serangkaian aktivitas yang tidak diizinkan dan melanggar hukum yang ditandai dengan bumbu kesengajaan untuk merugikan pihak lain agar memberikan keuntungan untuk diri sendiri". Menurut Cressey (1953) dalam Karyono (2013:8) menjelaskan bahwa ada tiga unsur yang mendukung fraud, yaitu tekanan (Pressure), kesempatan (Opportunity), dan pembenaran (Rationalization).

Pencegahan fraud merupakan seluruh usaha untuk mengurangi kesempatan dan mempersempit peluang terjadinya kecurangan (Karyono, 2013:47). Dapat disimpulkan bahwa pencegahan fraud merupakan suatu tindakan meminimalisasikan penyebab kecurangan sebelum terjadi. Karena apabila upaya pencegahan yang diterapkan oleh oleh suatu entitas, maka dapat meminimalisir kecurangan. Karyono (2013:61) menyebutkan bahwa pencegahan kecurangan dilakukan dengan Teori Triangle Fraud, yakni:

\section{Mengurangi "tekanan" yang memungkinkan kecurangan.}

2. Mengurangi "kesempatan" melakukan kecurangan.

3. Mengurangi "pembenaran" melakukan kecurangan.

\section{Sistem Pengendalian Internal Pemerintah (SPIP)}

Pengendalian Internal dalam lingkungan pemerintahan dan Sektor Publik disebut dengan Sistem Pengendalian Iternal Pemerintah (SPIP). Menurut Peraturan Pemerintah No. 60 tahun 2008 pasal 1 ayat (1), "SPIP adalah proses yang integral pada kegiatan dan tindakan yang dilakukan secara terus menerus oleh pimpinan dan tercapainya tujuan 
organisasi melalui kegiatan yang efektif dan efisien, keandalan pelaporan keuangan, pengamanan aset negara, dan ketaatan terhadap peraturan perundang- undangan". Sedangkan menurut Ichlas et. al (2014), "SPIP adalah SPI yang diselenggarakan secara menyeluruh untuk mencapai tujuan organisasi. Dapat disimpulkan bahwa pengendalian internal adalah sebuah prosedur yang mempunyai pengaruh besar dan memegang peran penting untuk mencapai kegiatan pemerintahan". Elemen Sistem Pengendalian Intern sebagaimana diatur dalam PP No.60 Ttahun 2008 terdiri atas lima unsur, yaitu: (1) lingkungan pengendalian, (2) penilaian risiko, (3) kegiatan pengendalian, (4) informasi dan komunikasi, dan (5) pemantauan pengendalian intern. Elemen-elemen tersebut membantu entitas dalam mencapai tujuannya.

\section{Peran Komite Sekolah}

Komite Sekolah adalah badan yang berdiri sendiri yang mengayomi peran serta masyarakat dalam rangka meningkatkan mutu, melakukan pemerataan (Kepmendiknas nomor: 044/U/2002). Tidak semua individu yang menyandang peran tertentu merasa terikat dengan peran tersebut karena hal demikian dapat berlawanan dengan peran lainnya sehingga tidak pernah ada dua individu yang menduduki satu peran dengan cara yang sama. Konflik tersebut dapat diatur dalam sebuah aturan yang jelas sebagaimana kaitannya dengan peran komite sekolah. Peran komite sekolah dalam Kepmendiknas Nomor 044//U/2002 adalah (1) pemberi pertimbangan, (2) pendukung, (3) pengontrol, dan (4) penghubung.

\section{Dana Bantuan Operasional Sekolah (BOS)}

Silele et al., (2017) mengatakan bahwa dana BOS merupakan program pemerintah untuk mebiayai kegiatan nonpersonalia sekolah untuk mewujudkan program wajib belajar. Menurut Peraturan Menteri Pendidikan Nasional Nomor 69 Tahun 2009 tentang Standar Biaya Operasi Nonpersonalia pada pasal 1 menjelaskan bahwa standar biaya operasi nonpersonalia adalah standar biaya yang diperlukan selama 1 (satu) tahun periode yang bertujuan agar satuan pendidikan dapat berjalan dengan teraratur dan berkelanjutan sesuai dengan aturan standar pendidikan nasional. BOS menjadi hal yang sangat penting dalam kegiatan operasi sekolah dan dalam kehidupan masyarakat karena dapat mengurangi beban masyarakat.

\section{Pengaruh SPIP Terhadap Pencegahan Fraud}

Menurut Susanto (2013:93) menyatakan bahwa: "Sistem pengendalian intern yang komprehensif, diterapkan secara menyeluruh dan memonitor secara reguler aktivitas suatu organisasi merupakan langkah penting untuk menjaga dan mendeteksi resiko kerugian yang diakibatkan oleh penyelewangan di bidang keuangan. Pengendalian intern sangat penting dalam mendeteksi adanya penyelewengan keuangan yang mengandung merugikan perusahaan." Apabila SPI dalam suatu organisasi dapat berjalan dengan efektif maka kewajiban yang didelegasikan kepada tiap anggota organisasi akan terlaksanakan dan pengendalian internal ini juga dapat mencegah atau mendeteksi berbagai kecurangan yang mungkin terjadi, serta akan mendorong organisasi untuk patuh terhadap aturan yang ada. Dalam PP No. 60 tahun juga sudah ditekankan apabila "organisasi sektor publik memiliki pengendalian internal yang efektif, akan mempengaruhi pada pencapaian pengelolaan keuanngan yang transparansi dan akuntabel sehingga dapat mengurangi resiko terjadinya kecurangan".

\section{Pengaruh Peran Komite Sekolah Terhadap Pencegahan Fraud}

Komite Sekolah adalah badan yang berdiri sendiri yang mengayomi peran serta masyarakat dalam rangka meningkatkan mutu, melakukan pemerataan (Kepmendiknas nomor: 044/U/2002). Peran komite sekolah tidak terbatas menyangkut urusan finansial dan fasilitas pendidikan saja, melainkan bidang-bidang lain yang menjadi faktor pendukung kemajuan pendidikan di sekolah perlu keterlibatan komite sekolah. Dana BOS termasuk bidang yang perlu keterlibatan dari komite sekolah. Komite sekolah memainkan peran yang penting dalam demokratisasi, transparansi, dan akuntabilitas sekolah serta jauh dari tindakan kecurangan yang tidak diinginkan. Tolak ukur keterlibatan Komite Sekolah dalam pengelolaan Dana BOS dapat dilihat dari keterlaksanaan keempat perannya. Keberadaan komite sekolah beserta perannya akan menjadi salah satu penentu dalam pengelolaan dana BOS. Dengan demikian hal-hal yang tidak diinginkan terkait kecurangan dana BOS dapat diantisipasi dan dicegah oleh komite sekolah sebelum tindak kecurangan 
terjadi. Hal ini didukung dengan penelitian yang dilakukan oleh Cahyanto (2014) yang menyatakan bahwa komite sekolah berpengaruh signifikan terhadap pengelolaan dana BOS berikut:

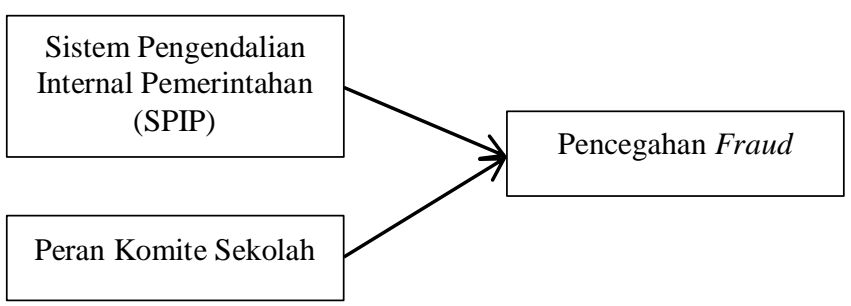

Gambar 2.1 Skema Kerangka Pemikiran

\section{Hipotesis :}

H1: SPIP dan Peran Komite Sekolah mempengaruhi pencegahan fraud pengelolaan dana BOS

$\mathrm{H} 2$ : SPIP mempengaruhi pencegahan fraud pengelolaan dana BOS

H3: Peran Komite Sekolah mempengaruhi pencegahan fraud pengelolaan dana BOS

\section{Metode Penelitian \\ Desain Penelitian}

Penelitian ini merupakan penelitian kuantitatif. Tujuan studi yang dilakukan dalam penelitian ini bersifat kausal dengan menguji hipotesis. Tingkat intervensi dalam penelitian ini minimal, penelitian ini mengunakan penelitian survei. Horizon waktu yang digunakan dalam penelitian ini adalah cross sectional.

\section{Peran Komite Sekolah}

Komite Sekolah adalah badan yang berdiri sendiri yang mengayomi peran serta masyarakat dalam rangka meningkatkan mutu, melakukan pemerataan (Kepmendiknas nomor: 044/U/2002). Pengukuran variabel ini menggunakan instrumen angket yang di modifikasi dari studi Cahyanto (2014) yang berjumlah 11 pernyataan.

\section{Populasi dan Sampel Penelitian}

Populasi yang akan digunakan dalam seluruh SMP Negeri di Banda Aceh yang berjumlah 19 sekolah. Metode pemilihan sampel menggunakan metode sensus atau lebih dikenal dengan sampel jenuh. Responden dalam penelitian ini adalah kepala sekolah, wakil kepala sekolah, dan bendahara BOS dari 19 sekolah yang berjumlah 57 orang.

\section{Operasionalisasi Variabel \\ Pencegahan Fraud}

Pencegahan fraud merupakan seluruh usaha untuk mengurangi kesempatan dan mempersempit peluang terjadinya kecurangan (Karyono, 2013:47). Variabel pencegahan fraud diukur dengan pernyataan yang dikembangkan dari studi Pura \& Sufiati (2014) yang berjumlah 12 item pernyataan.

\section{Sistem Pengendalian Internal (SPIP)}

Menurut Peraturan Pemerintah No. 60 tahun 2008 pasal 1 ayat (1), "SPIP adalah proses yang integral pada kegiatan dan tindakan yang dilakukan secara terus menerus oleh pimpinan dan tercapainya tujuan organisasi melalui kegiatan yang efektif dan efisien, keandalan pelaporan keuangan, pengamanan aset negara, dan ketaatan terhadap peraturan perundang-undangan". Pengukuran variabel ini menggunakan instrumen angket yang dimodifikasi dari studi Herawati (2014) yang berjumlah 15 item pernyataan.

\section{Teknik Pengumpulan Data}

Data primer dalam penelitian ini diperoleh dengan menyebarkan kuesioner yang berisi pertanyaan yang terkait dengan variabel penelitian kepada responden yang telah ditentukan sebelumnya. Agar penyebaran kuesioner lebih efektif, peneliti sendiri yang langsung mengantarkan kuesioner kepada responden dan akan diambil kembali jika kuesioner sudah selesai diisi sesuai dengan waktu yang telah disepakati antar peneliti dan responden demi menghindari kuesioner yang tidak kembali.

\section{Metode Penelitian}

Alat analisis yang digunakan dalam penelitian ini adalah analisis regresi linier berganda bertujuan untuk mengetahui pengaruh atau hubungan antara variabel bebas yaitu: SPIP (X1) dan peran komite sekolah (X2), terhadap variabel terikat yaitu pencegahan fraud $(\mathrm{Y})$. Perhitungan statistik dalam analisis regresi linier berganda yang dilakukan dalam penelitian ini adalah dengan menggunakan bantuan program SPSS.

Persamaan regresi linier berganda adalah sebagai berikut (Ghozali, 2016): 


$$
\mathrm{Y}=\mathrm{a}+\mathrm{b} 1 \mathrm{X} 1+\mathrm{b} 2 \mathrm{X} 2+\mathrm{b} 3 \mathrm{X} 3+\mathrm{e}
$$

Keterangan:

$\mathrm{Y}=$ Pencegahan Fraud

a $=$ Konstanta

$\mathrm{b} \quad=$ Koefisien Regresi

$\mathrm{X} 1=\mathrm{SPIP}$

$\mathrm{X} 2$ = Peran Komite Sekolah

$\mathrm{E}=$ Error
4. Hasil Dan Pembahasan

Uji Kualitas Data

Hasil Uji Validitas

Pengujian kualitas data dalam penelitian ini diuji secara statistik menggunakan uji koefisien korelasi product moment dengan nilai signifikansi sebesar 0,05 dibantu oleh SPSS. Butir pertanyaaan tersebut dikatakan valid apabila nilai $\mathrm{r}$ hitung lebih besar dari pada nilai $r$ tabel. Begitupun sebaliknya, jika $r$ hitung lebih kecil dari pada $r$ tabel, maka butir pertanyaan tersebut dikatakan tidak valid.

\begin{tabular}{|c|c|c|c|c|}
\hline Variabel & Item Pertanyaan & Koefisien Korelasi (R hitung) & Nilai Kritis 5\% (R tabel) & Ket \\
\hline \multirow{15}{*}{ SPIP } & SPIP1 & 0,814 & \multirow{15}{*}{0.2759} & Valid \\
\hline & SPIP2 & 0,726 & & Valid \\
\hline & SPIP3 & 0,386 & & Valid \\
\hline & SPIP4 & 0,710 & & Valid \\
\hline & SPIP5 & 0,799 & & Valid \\
\hline & SPIP6 & 0,466 & & Valid \\
\hline & SPIP7 & 0,415 & & Valid \\
\hline & SPIP8 & 0,755 & & Valid \\
\hline & SPIP9 & 0,661 & & Valid \\
\hline & SPIP10 & 0,831 & & Valid \\
\hline & SPIP11 & 0,686 & & Valid \\
\hline & SPIP12 & 0,673 & & Valid \\
\hline & SPIP13 & 0,625 & & Valid \\
\hline & SPIP14 & 0,725 & & Valid \\
\hline & SPIP15 & 0,515 & & Valid \\
\hline \multirow{11}{*}{$\begin{array}{l}\text { Peran Komite } \\
\text { Sekolah }\end{array}$} & PKS1 & 0,880 & \multirow{11}{*}{0.2759} & Valid \\
\hline & PKS2 & 0,937 & & Valid \\
\hline & PKS3 & 0,881 & & Valid \\
\hline & PKS4 & 0,827 & & Valid \\
\hline & PKS5 & 0,843 & & Valid \\
\hline & PKS6 & 0,541 & & Valid \\
\hline & PKS7 & 0,600 & & Valid \\
\hline & PKS8 & 0,500 & & Valid \\
\hline & PKS9 & 0,723 & & Valid \\
\hline & PKS10 & 0,674 & & Valid \\
\hline & PKS11 & 0,454 & & Valid \\
\hline \multirow{6}{*}{$\begin{array}{l}\text { Pencegahan } \\
\text { Fraud }\end{array}$} & PF1 & 0,638 & \multirow{6}{*}{0.2759} & Valid \\
\hline & PF2 & 0,595 & & Valid \\
\hline & PF3 & 0,355 & & Valid \\
\hline & PF4 & 0,296 & & Valid \\
\hline & PF5 & 0,558 & & Valid \\
\hline & PF6 & 0,382 & & $\begin{array}{l}\text { Valid } \\
\end{array}$ \\
\hline
\end{tabular}




\begin{tabular}{|c|c|c|c|c|}
\hline Variabel & Item Pertanyaan & Koefisien Korelasi (R hitung) & Nilai Kritis 5\% (R tabel) & Ket \\
\hline \multirow{4}{*}{} & PF7 & 0,439 & & Valid \\
\cline { 2 - 3 } & PF8 & 0,510 & Valid \\
\cline { 2 - 3 } & PF9 & 0,348 & Valid \\
\cline { 2 - 3 } & PF10 & 0,591 & Valid \\
\cline { 2 - 3 } & PF11 & 0,368 & Valid \\
\cline { 2 - 3 } & PF12 & 0,535 & Valid \\
\hline
\end{tabular}

\subsubsection{Hasil Uji Reliabilitas}

\begin{tabular}{|l|c|c|c|}
\hline \multicolumn{1}{|c|}{ Variabel } & $\begin{array}{c}\text { Cronbach } \\
\text { Alpha }\end{array}$ & $\begin{array}{c}\text { Nilai kritis } \\
\text { Cronbach } \\
\text { Alpha }\end{array}$ & Ket \\
\hline SPIP (X1) & 0,897 & 0,60 & Reliabel \\
\hline $\begin{array}{l}\text { Peran Komite } \\
\text { Sekolah (X2) }\end{array}$ & 0,766 & 0,60 & Reliabel \\
\hline $\begin{array}{l}\text { Pencegahan Fraud } \\
\text { (Y) }\end{array}$ & 0,675 & 0,60 & Reliabel \\
\hline
\end{tabular}

Berdasarkan tabel di atas, hasil uji reliabilitas menghasilkan nilai Cronbach Alpha masing-masing variabel yang lebih besar dari 0.60. dapat disimpulkan bahwa kuesioner pada penelitian ini dapat mencapai tujuan penelitian.

\section{Uji Asumsi Klasik}

\section{Hasil Uji Normalitas}

\begin{tabular}{|c|c|}
\hline & Unstandardized Residual \\
\hline Asymp. Sig. (2-tailed) & 0,856 \\
\hline
\end{tabular}

Dapat dilihat bahwa nilai signifikansi (Asymp. Sig. 2- tailed) sebesar 0,856. Nilai signifikansi lebih dari 0,05 , maka data tersebut terdistribusi secara normal.

\section{Hasil Uji Multikolinearitas}

\begin{tabular}{|l|c|c|}
\hline \multicolumn{1}{|c|}{ Model } & Tolerance & VIF \\
\hline $\begin{array}{l}\text { Sistem Pengendalian Internal } \\
\text { Pemerintah (SPIP) }\end{array}$ & 0,946 & 1,058 \\
\hline Peran Komite Sekolah & 0,946 & 1,058 \\
\hline
\end{tabular}

Pendeteksian multikolinearitas dapat dilakukan dengan melihat nilai Variance Inflasting Factor (VIF) dan nilai tolerance. Apabila nilai tolerance $>0,10$ dan nilai VIF <10, maka tidak terjadi multikolinearitas. Maka dapat disimpulkan bahwa tidak terjadi multikolinearitas. Hal ini dapat dibuktikan dengan masing-masing model memiliki nilai tolerance yang > 0,10 dan nilai $\mathrm{VIP}<10$

\section{Hasil Uji Heteroskedastisitas}

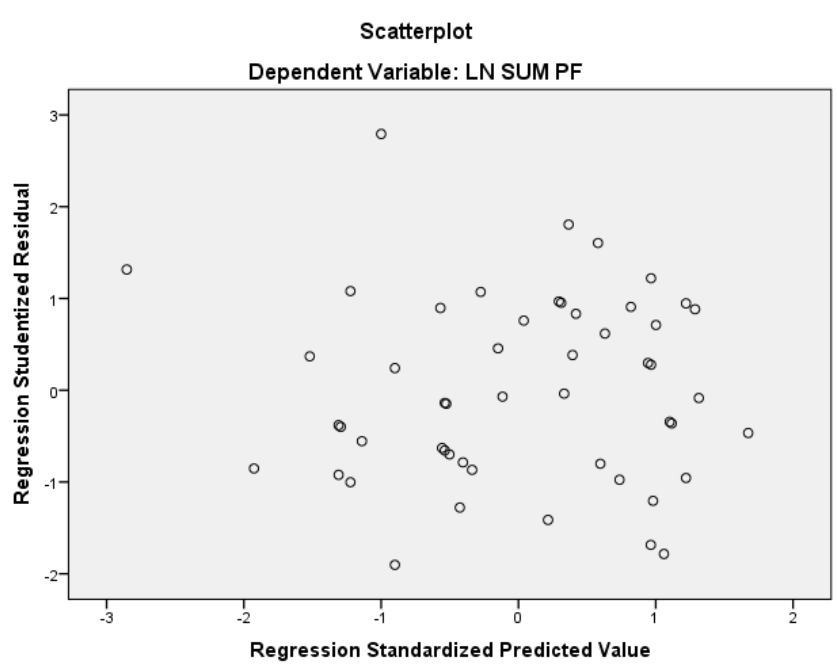

Pola pada grafik scatterplot dapat melihat apakah model regresi mengalami heterokedastisitas. Jika tidak terdapat pola tertentu atau titik-titik menyebar diatas dan dibawah angka 0 pada sumbu Y, maka tidak terjadi heterokedastisitas (Ghozali, 2016). Dapat dilihat bahwa tidak terdapat pola tertentu atau titik-titik yang menyebar di atas dan di bawah angka 0 pada sumbu Y, maka model regresi pada penelitian ini tidak terjadi heteroskedastisitas.

\section{Metode Analisis dan Rancangan Pengujian Hipotesis}

Metode Analisis Regresi Linear Berganda

\begin{tabular}{|l|c|c|c|c|c|}
\hline \multirow{2}{*}{ Model } & \multicolumn{2}{|c|}{$\begin{array}{c}\text { Unstandardized } \\
\text { Coefficients }\end{array}$} & $\begin{array}{c}\text { Standardiz } \\
\text { ed } \\
\text { Coefficient } \\
\text { s }\end{array}$ & t & \multirow{2}{*}{ Sig. } \\
\cline { 2 - 4 } & B & $\begin{array}{c}\text { Std. } \\
\text { Error }\end{array}$ & Beta & & \\
\hline 1 (Constant) & 1,496 & 0,336 & & $\begin{array}{c}4,09 \\
1\end{array}$ & 0,000 \\
\hline SPIP & 0,387 & 0,068 & 0,587 & $\begin{array}{c}5,68 \\
1\end{array}$ & 0,000 \\
\hline $\begin{array}{l}\text { Peran Komite } \\
\text { Sekolah }\end{array}$ & 0,225 & 0,078 & 0,297 & $\begin{array}{c}2,87 \\
4\end{array}$ & 0,006 \\
\hline
\end{tabular}


Berdasarkan hasil perhitungan statistik dengan menggunakan program SPSS seperti Tabel 4.12 maka diperoleh persamaan regresi linier berganda sebagai berikut.

$$
Y=1,496+0,387 X_{1}+0,225 X_{2}+\varepsilon
$$

Dari persamaan regresi dapat diketahui hasil penelitian dari masing-masing koefisien yaitu untuk konstanta $(\mathrm{a}=1,496)$ artinya jika faktor-faktor Sistem Pengendalian internal pemerintah (X1), dan peran komite sekolah (X2) dianggap konstan atau dianggap nol (tidak ada), maka dapat disimpulkan bahwa besarnya pencegahan fraud pengelolaan dana BOS pada SMP Negeri di Banda Aceh adalah sebesar 1,496. Nilai konstanta 1,496 juga menunjukkan bahwa kedua variabel bebas dapat memberikan kontribusi untuk mempengaruhi pencegahan fraud sebesar kelipatan 1,496 .

Koefisien regresi dari variabel SPIP (X1) adalah sebesar 0,387, yang bermakna bahwa setiap ada peningkatan sebesara satu satuan pada variabel SPIP, maka secara relatif akan meningkatkan pencegahan fraud pengelolaan dana BOS pada SMP Negeri di Banda Aceh sebesar 38,7\%. Dengan demikian semakin baik sistem pengendalian internal pemerintah (SPIP) maka secara relatif akan meningkatkan pencegahan fraud pengelolaan dana BOS pada SMP Negeri di Banda Aceh.

Koefisien regresi peran komite sekolah adalah sebesar 0,225, yang bermakna bahwa jika peran komite sekolah meningkat 1 satuan, maka secara relatif akan meningkatkan pencegahan fraud sebesar 22,5\%. Dengan demikian semakin baik peran komite sekolah maka secara relatif akan meningkatkan pencegahan fraud pengelolaan dana BOS pada SMP Negeri di Banda Aceh.

Selanjutnya berdasarkan data pada Tabel 4.12 di atas dapat diketahui nilai koefisien korelasi (R) dan koefisien determinansi atau adjust $R$ Square. Koefisien korelasi menunjukkan besarnya hubungan antar variabel yaitu variabel bebas dan variabel terikat. Jika angka koefisien korelasi mendekati 1, maka kedua variabel mempunyai hubungan semakin kuat. Berdasarkan Tabel 4.12, diketahui nilai koefisien korelasi sebesar 0,718 yang berarti bahwa terdapat hubungan yang kuat antara sistem pengendalian internal pemerintah dan peran komite sekolah dengan pencegahan fraud.

Sedangkan nilai koefisien determinasi menunjukkan besarnya pengaruh variabel bebas terhadap variabel terikat. Nilai koefisien korelasi dalam penelitian ini sebesar $51,5 \%$ yang berarti bahwa sistem pengendalian internal pemerintah dan peran komite sekolah mempengaruhi pencegahan fraud pengelolaan dana BOS pada SMP Negeri Banda Aceh sebesar 51,5 $\%$, sedangkan sisanya sebesar $48,5 \%$ dipengaruhi oleh variabel lain yang tidak diteliti dalam penelitian ini.

\section{Pengujian Hipotesis}

\section{Pengujian Secara Simultan (Uji Statistik F)}

\begin{tabular}{|l|c|c|c|c|c|}
\hline Model & $\begin{array}{l}\text { Sum of } \\
\text { Square }\end{array}$ & df & $\begin{array}{l}\text { Mean } \\
\text { Square }\end{array}$ & F & Sig \\
\hline Regression &, 073 & 2 &, 037 & 25,466 & 0,000 \\
\hline Residual &, 069 & 48 &, 001 & & \\
\hline
\end{tabular}

Nilai sig 0,000 artinya lebih kecil dari 0,05 sehingga hipotesis dapat diterima, maka dapat disimpulkan bahwa SPIP dan peran komite sekolah berpengaruh secara simultan terhadap pencegahan fraud pengelolaan dana BOS pada SMP Negeri di Banda Aceh.

\section{Pengujian Secara Parsial (Uji Statistik T)}

\begin{tabular}{|l|l|l|l|l|l|}
\hline Model & \multicolumn{2}{|l|}{$\begin{array}{l}\text { Unstandardized } \\
\text { Coefficients }\end{array}$} & $\begin{array}{l}\text { standardized } \\
\text { Coefficients }\end{array}$ & t & sig \\
\cline { 2 - 5 } & B & $\begin{array}{l}\text { Std. } \\
\text { Error }\end{array}$ & Beta & & \\
\hline 1 (Constant) & 1,496 & 0,336 & & 4,091 & 0,000 \\
\hline SPIP & 0,387 & 0,068 & 0,587 & 5,681 & 0,000 \\
\hline PKS & 0,225 & 0,078 & 0,297 & 2,874 & 0,006 \\
\hline
\end{tabular}

Berdasarkan hasil uji parsial, maka diperoleh beberapa hal yang dapat disimpulkan sebagai berikut:

1) Pada hasil pengujian statistik di atas diketahui nilai t statistik atau thitung variabel SPIP adalah 5,681 dan nilai ini lebih besar tTabel $(5,681>2,01)$ dan juga memiliki tingkat signifikansi $0,000<$ 0,05. Sehingga dapat dinyatakan $\mathrm{H}_{\mathrm{a} 1}$ diterima, dengan kata lain dapat disimpulkan bahwa SPIP berpengaruh signifikan terhadap pencegahan fraud.

2) Pada hasil pengujian statistik di atas diketahui nilai 
thitung variabel peran komite sekolah adalah 2,874 yang mana nilai ini lebih besar dari tTabel $(2,874>2,01)$ dan juga memiliki tingkat signifikansi $0,006<0,05$. Sehingga dapat dinyatakan $\mathrm{H}_{\mathrm{a}} 2$ diterima, dengan kata lain dapat disimpulkan bahwa peran komite sekolah berpengaruh signifikan terhadap pencegahan fraud.

\section{Pembahasan}

\section{Pengaruh SPIP Terhadap Pencegahan Fraud}

Berdasarkan hasil uji statistik yang dilakukan dalam pengujian hipotesis ditemukan bahwa SPIP memiliki pengaruh secara signifikan terhadap pencegahan fraud. Menurut Peraturan Pemerintah No 60 Tahun 2008 tentang Sistem Pengendalian Intern Pemerintah Pasal 2 bahwa SPIP dirancang bertujuan untuk memberikan keyakinan memadai tercapainya efektivitas dan efisiensi penyelenggaraan urusan pemerintahan, keandalan pelaporan keuangan, pengamanan terhadap aset negara, dan ketaatan terhadap peraturan perundang-undangan. Berdasarkan pengertian tersebut dapat dilihat bahwa pengendalian internal adalah sebuah prosedur yang mempunyai pengaruh besar dan memegang peran penting untuk mencegah kecurangan. Hal tersebut juga didukung oleh adanya lima komponen SPIP. Komponen pertama yaitu lingkungan pengendalian telah didukung dengan adanya pemisahan tugas dan tanggung jawab untuk pengelola dana BOS, SOP pelaksanaan kegiatan dana BOS telah disusun dan ditetapkan, terdapat nilai dasar dan kode etik di instansi sekolah. Pada komponen penilaian risiko telah didukung oleh terdapatnya Kerangka Acuan Kegiatan (KAK) yang memuat tahapan kegiatan, tujuan, target, dan jadwal pelaksanaan kegiatan yang bersumber dari dana BOS. Pada komponen Kegiatan pengendalian telah didukung dengan terdapat pengendalian atas pengelolaan sistem informasi seperti pembatasan akses berdasarkan tanggung jawab, pengendalian berupa updating data dilakukan secara berkala, dan adanya kegiatan review capaian indikator kinerja secara berkala terhadap pengelolaan Dana BOS. Pada komponen Informasi dan komunikasi, terdapatnya laporan hasil pengelolaan dana BOS yang telah menyajikan kondisi lapangan, kendala dan rekomendasi untuk mengatasi permasalahan yang dihadapi, serta sekolah memiliki prosedur tertulis dan petugas khusus untuk pengembangan sistem informasi dan komunikasi.
Komponen SPIP yang kelima yaitu pemantauan didukung dengan terdapatnya prosedur pemantauan berkelanjutan yang digunakan sebagai acuan dalam pelaksanaan pemantauan pengelolaan dana BOS, serta pimpinan juga melakukan rapat dengan pegawai untuk meminta masukan tentang efektivtas pengendalian internal.

Penjelasan di atas membuktikan bahwa peningkatan SPIP juga meningkatkan pencegahan fraud pengelolaan dana BOS pada SMP Negeri di Banda Aceh, di mana dengan adanya sistem pengendalian yang efektif, maka kegiatan operasional juga dapat berjalan secara efektif dan juga efisien sehingga kemungkinan adanya penyimpangan dalam proses operasional instansi juga dapat diminimalisir.

Hasil penelitian ini sejalan dengan penelitian Pura \& Sufiati (2014), On Joseph et al. (2015), Ariastini et al. (2017),Yuniarti (2017) dan Maliawan (2017). Hasil penelitian ini memberikan butkti empiris bahwa pengendalian intern berpengaruh terhadap pencegahan kecurangan, dimana pengendalian intern yang baik akan meningkatkan pencegahan kecurangan.

\section{Pengaruh Peran Komite Sekolah Terhadap Pencegahan Fraud}

Berdasarkan hasil uji statistik yang dilakukan dalam pengujian hipotesis ditemukan bahwa peran komite sekolah memiliki pengaruh secara signifikan terhadap pencegahan fraud. Komite sekolah mempunyai peranan penting dalam demokratisasi, transparansi, dan akuntabilitas sekolah serta jauh dari tindakan kecurangan yang tidak diinginkan. Tolak ukur keterlibatan Komite Sekolah dalam pengelolaan Dana BOS dapat dilihat dari keterlaksanaan keempat perannya yang telah ditetapkan dalam Keputusan Menteri Pendidikan Nasional Nomor 044//U/2002 tentang Dewan Pendidikan dan Komite Sekolah, yang antara lain sebagai: badan pertimbangan (advisory agency), badan pendukung (supporting agency), badan pengontrol (controlling agency), dan badan penghubung (mediator agency). Keberadaan komite sekolah beserta perannya akan menjadi salah satu penentu dalam pengelolaan dana BOS yang meliputi mekanisme pengambilan dana BOS, mekanisme penggunaan dana BOS dan pertanggungjawaban sekolah. Dengan demikian hal-hal yang tidak diinginkan terkait kecurangan dana BOS dapat diantisipasi dan dicegah oleh komite sekolah 
sebelum tindak kecurangan terjadi.

Hasil penelitian ini konsisten dengan hasil penelitian yang dilakukan Cahyanto (2014) yang menyatakan komite sekolah berpengaruh terhadap pengelolaan dana BOS, sehingga adanya Komite akan memberikan kontrol terhadap Pengelolaan Dana BOS.

\section{Kesimpulan, Keterbatasan Dan Saran \\ Kesimpulan}

1. Sistem Pengendalian Internal Pemerintah (SPIP) berpengaruh terhadap pencegahan fraud pengelolaan dana BOS pada SMP Negeri di Banda Aceh

2. Peran komite sekolah berpengaruh terhadap pencegahan fraud pengelolaan dana BOS pada SMP Negeri di Banda Aceh

3. Sistem Pengendalian Internal Pemerintah (SPIP) dan peran komite sekolah secara simultan berpengaruh terhadap pencegahan fraud pengelolaan dana BOS pada SMP Negeri di Banda Aceh

\section{Keterbatasan Penelitian}

Penelitian ini memiliki beberapa kelemahan yang membatasi kesempurnaannya. Oleh karena itu, keterbatasan ini perlu diperhatikan dalam penelitian selanjutnya. Adapun keterbatasan tersebut sebagai berikut :

1. Instrumen yang digunakan dalam pengumpulan data yang berupa kuesioner tertutup, sehingga jawaban yang diberikan responden terbatas pada pernyataan-pernyataan yang diberikan oleh peneliti.

2. Kesimpulan yang diambil hanya berdasarkan data yang dikumpulkan melalui kuesioner sehingga akan menimbulkan masalah jika jawaban responden berbeda dengan keadaan yang sebenarnya, apalagi jika kuesioner tersebut diisi oleh responden dengan keadaan kurang konsentrasi, maka keadaan yang seperti itu merupakan hal yang tidak dapat dikendalikan dan diluar batas kemampuan peneliti.

\section{Saran-Saran Penelitian}

1. Untuk penelitian selanjutnya, dapat dilakukan dengan metode lain misalnya dengan melakukan wawancara secara langsung dengan responden dalam pengisian kuesioner sehingga jawaban responden lebih mencerminkan jawaban yang sebenarnya.

2. Pengaruh secara bersama-sama yang diperoleh adalah sebesar $51,5 \%$ yang mana masih terdapat $48,5 \%$ dipengaruhi oleh variabel lain. Berdasarkan hal tersebut diharapkan untuk peneliti selanjutnya menambahkan variabel lain seperti kompetensi sumber daya manusia, proactive fraud audit, whistlebowing system, dan sebagainya.

\section{Daftar Pustaka}

Agoes, Sukrisno. 2014. Auditing (Petunjuk Praktis Pemeriksaan Akuntan oleh Akuntan Publik). Jakarta: Salemba Empat.

Azwar, Saifuddin. 2010. Metode Penelitian. Yogyakarta: Pustaka Pelajar.

Andi, M., AR, M., Usman, N. (2015). Efektivitas Penggunaan Dana Bantuan Operasional Sekolah pada Madrasah Ibtidaiyah Swasta di Kabupaten Pidie. Jurnal Administrasi Pendidikan, 3(4), 5363.

Arens, A.A., Elder, R.J., \& Beasley,M.S. 2015. Auditing dan Jasa Assurance: Pendekatan Terintegrasi. Edisi 15. (Alih bahasa: Herman Wibowo). Jakarta: Penerbit Erlangga.

Ariastini, Ni Kadek Dwi., Gede Adi Yuniarta., \& Putu Sukma Kurniawan. (2017). Pengaruh Kompetensi Sumber Daya Manusia, Sistem Pengendalian Internal Pemerintah, Proactive Fraud Audit, dan Whistleblowing System Terhadap Pencegahan Fraud Pada Pengelolaan Dana BOS Se-Kabupaten Klungkung. E-journal S1 Ak Universitas Pendidikan Ganesha, 8(2)

Arikunto, Suharsimi. 2013. Prosedur Penelitian Suatu Pendekatan Praktik. Jakarta: Rineka Cipta

Association of Certified Fraud Examiner. 2014. Report To The Nations on Occupational Fraud and Abuse. Canada: Global Headquarters.

Association of Certified Fraud Examiner (ACFE). 2010. Report To The Nations On Occupational Fraud And Abuse 
ACFE Indonesia Chapter. "Survai Fraud Indonesia Association of Certified Fraud Examiners (ACFE) Indonesia Chapter, 2016.

Badan Pemeriksa Keuangan RI. 2007. Peraturan Badan Pemeriksa Keuangan RI No 1, Tahun 2007 tentang SPKN. Jakarta: Badan Pemeriksa Keuangan RI.

Badan Pemeriksa Keuangan RI. 2017. Peraturan Badan Pemeriksa Keuangan RI No 1, Tahun 2017 tentang SPKN. Jakarta: Badan Pemeriksa Keuangan RI.

Baridwan, Zaki. 2013. Sistem Informasi Akuntansi. Yogyakarta: BPFE

Bastian, Indra. 2018. Audit Sektor Publik:Pemeriksaan Pertanggungjawaban Pemerintahan. Jakarta: Salemba Empat.

Cahyanto, Aprizal Happy. 2014. Pengaruh Peran Komite Dan Pengawas Sekolah Terhadap Pengelolaan Dana Bos Di SMPN 2 Geger Kab. Madiun. Forum Ilmiah Pendidikan Akuntansi. Madiun.

Depdiknas. 2002. Keputusan Menteri Pendidikan Nasional Nomor : 044/U/2002. tentang dewan pendidikan dan komite sekolah: Jakarta: Ditjen Dikdasmen.

Egi. (2016). Kerugian Negara Dari Korupsi Sektor Pendidikan Capai 1,3 Triliun Rupiah. Antikorupsi.org (online). Harian Rabu, 18 Mei

2016. (https://antikorupsi.org/id/news/kerugian- negaradari-korupsi-sektor-pendidikan-capai-13-triliunrupiah). Di akses 28 Februari 2019

Erwanti, Marlinda Oktavia. (2018). KPK Temukan Korupsi Paling Banyak di Sektor Pendidikan. News.detik.com (online). Harian Senin, 19 Maret 2018. (https://news.detik.com/berita/d3923898/kpk-temukan-korupsi-paling-banyak-disektor-pendidikan). Di akses 28 Februari 2019

Fazini, Harum Nazra., \& Suparno. (2018). Pengaruh Sumber Daya Manusia Dan Pengendalian Internal Terhadap Kecurangan Akuntansi Studi Pada PT Pegadaian (Persero) Di Kota Banda Aceh. Jurnal Ilmiah Mahasiswa Ekonomi Akuntansi (JIMEKA). 3(4), 625-637.
Ghozali, Imam. 2013. Aplikasi Analisis Multivariate dengan Program IBM SPSS 20. Semarang: BPFE Universitas Diponegoro.

Ichlas, Muhammad., Hasan Basri, \& Muhammad Arfan. (2014). Pengaruh Penerapan Standar Akuntansi Pemerintahan, Sistem Pengendalian Intern Pemerintah dan Aksesibilitas Laporan Keuangan Terhadap Akuntabilitas Keuangan Pemerintah Kota Banda Aceh. Jurnal Magister Akuntamsi Pascasarjana Universitas Syiah Kuala. 3(4), 76-84.

Iskandar, Dedi. (2016). Korupsi Dana BOS, Mantan Kepsek SMPN di Nagan Raya Divonis Satu Tahun Penjara. Aceh.tribunnews.com. Harian Miggu, $24 \quad$ September 2017. http://aceh.tribunnews.com/2017/09/24/korupsidana-bos-mantan-kepsek-smpndi-nagan-rayadivonis-satu-tahun-penjara. Di akses 28 Februari 2019 .

Joseph, Oguda Ndege., Odhiambo Albert., \& Prof John Byaruhanga. 2015. Effect of Internal Control on Fraud Detection and Prevention in District Treasuries of Kakamega County. International Journal of Business and Management Invention, 4(1), 47-57.

Karyono. 2013. Forensic Fraud. Yogyakarta: CV. Andi.

Kemdikbud. Bantuan Operasional Sekolah. Melalui <http://bos.kemdikbud.go.id/index.php>.

Kuncoro, Mudrajad. 2014. Metode Riset untuk Bisnis dan Ekonomi. Erlangga: Jakarta.

Mahmudi. 2015. Manajemen Kinerja Sektor Publik. Yogyakarta: UPP STIM YKPN.

Maliawan, Ida Bagus., Edy Sujana., I Putu Gede Diatmika. (2017) Pengaruh Audit Internal Dan Efektivitas Pengendalian Interen Terhadap Pencegahan Kecurangan (Fraud). Jurnal Akuntansi Universitas Pendidikan Ganesha, 8(2).

Mulyadi. 2016. Sistem Akuntansi. Jakarta: Salemba Empat

Mulyono, M.A. 2008. Manajemen Administrasi \& Organisasi Pendidikan. Yogyakarta: Ar-Ruzz Media. 
Pratiwi, S. N. 2016. Manajemen Berbasis Sekolah dalam Meningkatkan Kualitas Sekolah. Jurnal EduTech, 2 (1).

Pura, Rahman., \& Sufiati. (2014). Implikasi Penerapan Internal Control Terhadap Pencegahan Fraud atas Pengelolaan Dana BOS. Jurnal Ekonomi, Manajemen, dan Akuntansi, 4(2), 218-224

Pusdiklatwas BPKP. 2008. Etika dalam Fraud. Jakarta: BPKP.

Republik Indonesia. (1945). Undang-Undang Dasar 1945

(2003). Undang-Undang Dasar Republik Indonesia Nomor 20 Tahun 2003 Tentang Sistem Pendidikan Nasional.

. (2005). Peraturan Pemerintah Nomor 48

Tahun 2005 Tentang Pendanaan Pendidikan. (2008). Peraturan Pemerintah Nomor 60

Tahun 2008 tentang Sistem Pengendalian Intern Pemerintah.

(2009). Peraturan Menteri Pendidikan Nasional Nomor 69 Tahun 2009 Tentang Pembiayaan Pendidikan.

(2016). Peraturan Menteri Pendidikan dan Budaya Nomor 75 Tahun 2016 Tentang Komite Sekolah

(2018). Peraturan Menteri Pendidikan dan Budaya Nomor 1 Tahun 2018 tentang Petunjuk Teknis Bantuan Operasional Sekolah.

Santama, Jefris. (2017). Diduga Pungli Dana BOS, Kadisdik Langkat dan 10 Orang Diamankan. News.detik.com (online). Harian Selasa, 17 Oktober 2017. (https://news.detik.com/berita/d3688305/diduga-pungli-dana-bos-kadisdiklangkat-dan-10-orang-diamankan). Di akses 28 Februari 2019

Sekaran, Uma dan Roger Bougie. 2017. Metode Penelitian untuk Bisnis Pendekatan Pengembangan-Keahlian. Edisi 6. Buku 1. Jakarta: Salemba Empat.

Sekaran, Uma dan Roger Bougie. 2017. Metode Penelitian untuk Bisnis Pendekatan Pengembangan-Keahlian. Edisi 6. Buku 2.
Jakarta: Salemba Empat.

Silele, E., Sabijono, H., Pusung, R. J. (2017). Evaluasi Pengeloaan Dana Bantuan Operasional Sekolah (BOS) (Studi Kasus pada SD Inpres 4 Desa Akediri Kecamatan Jailolo Kabupaten Halmahera Barat), EMBA, 5 (2), 1626-1635.

Sugiyono. 2017. Metode Penelitian Kuantitatif dan $R \& D$. Bandung: CV.Alfabeta.

Sumardiyani, Windiyati Retno. (2018). Diduga Korupsi Dana BOS, Kepala Sekolah di Tasikmalaya Ini Tertangkap Tangan. Pikiranrakyat.com (online). Harian Jumat, 11 Mei

2018. (https://www.pikiran-rakyat.com/jawabarat/2018/05/11/diduga-korupsi-dana-boskepala-sekolah-di-tasikmalaya-ini-tertangkaptangan). Di akses 28 Februari 2019

Susanto, Azhar. 2013. Sistem Informasi Akuntansi. Lingga Jaya:Bandung

Transparency International. 2018. Corruption Perception Index. Berlin: Transparency Interational

Transparency International. 2018. Corruption Perception Index. Germany: Transparency International.

Tuannakotta, Theodorus. M. 2017. Akuntansi Forensik dan Auditor Investigatif. Salemba Empat. Edisi ke 2: Jakarta.

Tugiman, Hiro. 2014. Pandangan Baru Internal Auditing. Kanisius:Yogyakarta

Yadi Haryadi. 2006. Pemberdayaan Komite Sekolah, Penguatan Kelembagaan Komite Sekolah. Jakarta : Ditjen Mandikdasmen.

Yuniarti, Dewi Rozmita. (2017). The Effect of Internal Control and Anti-fraud awareness on fraud prevention (A survey on inter-governmental organizations). Journal of Economics, Business, and Accountancy Ventura, 20(1), 113-124. 